\title{
PENGEMBANGAN SISTEM INFORMASI PERAMALAN PENJUALAN GUNA MENENTUKAN KEBUTUHAN BAHAN BAKU PUPUK MENGGUNAKAN METODE TRIPLE EXPONENTIAL SMOOTHING
}

\author{
Ely Setyo Astuti ${ }^{1}$, Putra Prima Arhandi ${ }^{2}$, Pipik Lestari ${ }^{3}$ \\ ${ }^{1,2,3}$ Program Studi Teknik Informatika, Jurusan Teknologi Informasi, Politeknik Negeri Malang \\ ${ }^{1}$ ely.setyo.astuti@polinema.ac.id, ${ }^{2}$ putraprima@gmail.com, ${ }^{3}$ lestaripipik@gmail.com
}

\begin{abstract}
Abstrak
Perkembangan bisnis di dunia industri mengalami perkembangan yang sangat pesat, salah satunya adalah perusahaan pupuk yang bergerak di jasa penyedia pupuk untuk memenuhi kebutuhan petani. Masa pemupukan tanaman yang dilakukan oleh para petani sangat dipengaruhi oleh faktor musim. Hal tersebut mempengaruhi jumlah permintaan produk pupuk yang berbeda setiap periodenya pada perusahaan. Perusahaan perlu memperhatikan aspek produksi pupuk akibat penumpukan dan kurangnya kebutuhan bahan baku pupuk pada gudang pada saat produksi pupuk berlangsung. Forecasting merupakan kegiatan untuk memprediksi nilai-nilai atau kejadian pada masa mendatang. Metode forecasting yang tepat dapat membantu perencanaan bisnis yang baik dalam perusahaan. Pengolahan dan analisis data penjualan masa lampau dapat digunakan untuk proses forecasting, sehingga didapatkan gambaran dan infomasi mengenai kebutuhan bahan baku yang di butuhkan selama proses produksi. Dalam penelitian kali ini, dilakukan Pengembangan Sistem Informasi Peramalan Penjualan Guna Menentukan Kebutuhan Bahan Baku Pupuk Menggunakan Metode Triple Exponential Smoothing. Sistem ini dapat membantu peramalan penjualan yang kemudian dapat di breakdown ke kebutuhan bahan baku yang dibutuhkan oleh perusahaan dengan menggunakan metode Triple Exponential Smoothing. Metode Triple Exponential Smoothing dapat diimplementasikan pada data penjualan pupuk dari tahun 2013, 2014, dan 2015 yang mempunyai unsur time series musim dan trend. Sistem ini dapat digunakan untuk meramalkan penjualan pupuk guna menentukan kebutuhan bahan baku pupuk subsidi sampe hasil peramalan pupuk subsidi urea sebesar 29.966 ton sehingga breakdown bahan baku urea berupa amoniak sebesar 17.320 ton dan $\mathrm{CO} 2$ sebesar 22.175 ton dengan rata-rata hasil akurasi yang bagus yaitu sebesar 14,63\%. Tetapi sistem tidak dapat digunakan sebagai sistem peramalan penjualan guna menentukan kebutuhan bahan baku pupuk non subsidi karena hasil akurasi yang kurang bagus yaitu sebesar $34,42 \%$.
\end{abstract}

Kata kunci : Forecasting, Penjualan, Stok Bahan Baku, Triple Exponential Smoothing

\section{Pendahuluan}

\subsection{Latar Belakang}

Perkembangan teknologi komputer di dunia bisnis meng Perkembangan teknologi komputer di dunia bisnis mengalami perkembangan yang sangat pesat mulai dari hardware maupun software. Seiring dengan dengan perkembangan teknologi tersebut kondisi persaingan bisnis menjadi semakin variatif dan kompetitif. Hal ini disebabkan adanya tuntutan konsumen terhadap suatu produk yang tidak terbatas pada harga dan kualitas tetapi juga pada pelayanan yang diberikan khususnya pada produk pupuk. Hal tersebut menuntut perusahaan untuk dapat merencanakan semua parameter produksi dengan baik, temasuk stok bahan baku dengan jumlah yang sesuai, sehingga diharapkan keuntungan pasar akan meningkat.

Adanya persaingan bisnis dan permintaan pasar khususnya di bidang pertanian khusunya pupuk, menuntut perusahaan berusaha untuk menstabilkan segala sudut produksi. Namun, dalam upaya tersebut seringkali terdapat beberapa faktor yang tidak sesuai kebutuhan khususnya masalah stok bahan baku produk pupuk. Hal tersebut terjadi karena perusahaan belum memiliki sistem khusus untuk meramalkan jumlah stok bahan baku yang dibutuhkan pada periode yang akan datang. Perusahaan menyesuaikan jumlah stok bahan baku yang dibeli pada periode tertentu dengan jumlah produksi pupuk pada periode tersebut. Dari proses tersebut mengakibatkan stok bahan baku mengalami penumpukan bahkan kekurangan stok bahan dalam proses produksi pupuk dalam periode waktu tertentu. Sedangkan perusahaan memiliki data-data yang dapat digunakan untuk menunjang proses bisnis. Dimana data-data tersebut dapat diolah lebih lanjut untuk memberikan keuntungan bagi perusahaan. Contohnya, untuk memprediksi stok bahan baku di masa yang akan datang dengan melakukan forecasting.

Peramalan (forecasting) merupakan kegiatan memprediksi nilai-nilai sebuah variabel berdasarkan 
nilai yang diketahui dari variabel tersebut atau variabel yang berhubungan Makridakis, dkk (1999)1. Peramalan (forecasting) merupakan teknik atau cara kuantitatif dalam memperkirakan apa yang akan terjadi pada masa mendatang, dan tentunya membutuhkan data-data masa lampau sebagai acuan atau data historis. Salah satu manfaat peramalan penjualan adalah dapat memperkirakan penjualan secara akurat dari waktu ke waktu. Sehingga dapat diprediksi kuantitas stok bahan baku yang dibutuhkan oleh perusahaan.

Dari permasalahan tersebut, perlu dilakukan implementasi peramalan stok bahan baku pupuk dengan metode peramalan yang tepat. Banyak metode yang dapat digunakan untuk proses peramalan diantaranya moving average, exponential smoothing, ARIMA, Naïve. Penelitian sejenis yang telah dilakukan oleh Ni Ketut Dewi Ari Jayanti, mahasiswa STMIK STIKOM Bali (2015), yang berjudul "Penerapan Metode Triple Exponential Smoothing pada Sistem Peramalan Penentuan Stok Obat", pada penelitian tersebut dilakukan pengolahan data penjualan obat untuk membantu peramalan kebutuhan obat yang disediakan oleh apotek. Penelitian tentang peramalan yang dilakukan oleh Muhammad Iqbal, mahasiswa jurusan teknik informatika fakultas teknik Universitas Muhammadiyah Jember (2016), dengan judul "Sistem Peramalan Menggunakan Metode Triple Exponential Smothing untuk Stok Bahan Spare Part Motor di Daruda Motor Jajag". Pada penelitian tersebut, aplikasi yang dibuat dapat memberikan peramalan mengenai stok bahan spare part motor di Garuda Motor Jajag. Pada penelitian kali ini dilakukan implementasi Business Intelligence Forecasting Stok Bahan Baku Pupuk Menggunakan Metode Triple Exponential Smoothing untuk meramalkan stok bahan baku pupuk pada periode selanjutnya. Dengan penelitian tersebut diharapkan dapat membantu proses peramalan penjualan guna menentukan kebutuhan bahan baku pupuk pada perusahaan pupuk.

\subsection{Rumusan Masalah}

1. Bagaimana membuat sebuah sistem informasi yang dapat membantu peramalan penjualan guna menentukan kebutuhan bahan baku pupuk?

2. Bagaimana implementasi metode Triple Exponential Smoothing pada sistem informasi peramalan penjualan guna menentukan kebutuhan bahan baku pupuk berbasis website?

\subsection{Batasan Masalah}

1. Sistem dibuat untuk membantu meramalkan stok bahan baku pupuk pada perusahaan pupuk.

2. Data yang digunakan dalam proses peramalan stok bahan baku pupuk adalah data penjualan pupuk tahun 2013, 2014, 2015 dari PT. Petrokimia Gresik.

3. Sistem ini meramalkan jumlah penjualan dan jumlah stok bahan baku pada 1 bulan ke depan.

4. Produk yang diramalkan adalah produk pupuk urea, ZA, SP-36, Phonska, dan ZK.

5. Sistem dibuat dengan berbasis website.

\subsection{Tujuan}

1. Membuat sistem informasi yang dapat membantu peramalan penjualan guna menentukan kebutuhan bahan baku pupuk.

2. Implementasi metode Triple Exponential Smoothing pada sistem informasi peramalan penjualan guna menentukan kebutuhan bahan baku pupuk berbasis website.

\section{Landasan Teori}

\subsection{Peramalan}

Peramalan (forecasting) merupakan kegiatan memprediksi nilai-nilai sebuah variabel berdasarkan nilai yang diketahui dari variabel tersebut atau variabel yang berhubungan Makridakis, dkk (1999).

Forecasting adalah peramalan atau perkiraan mengenai sesuatu yang belum terjadi. Peramalan biasanyadilakukan dengan menggunakan data dari masa lalu yang dianalisis dengan menggunakan metode-metode tertentu. Melalui forecasting diharapkan dapat meminimalisasi pengaruh ketidakpastian dari masa depan. Sehingga mendapatkan nilai forecast yang memiliki kesalan peramalan atau forecast error yang paling minimum merupakan tujuan dari forecasting. Hal ini menunjukkan bahwa forecasting merupakan alat bantu yang sangat penting dalam perencanaan yang efektif dan efisien.

\subsection{Triple Exponential Smoothing}

Metode Triple Exponential Smoothing digunakan ketika terdapat unsur musiman trend dan perilaku musiman yang ditunjukkan pada data. Metode Exponential Smoothing yang dapat digunakan untuk hampir segala jenis data stasioner atau non- stasioner sepanjang data tersebut tidak mengandung faktor musiman. Tetapi apabila terdapat data musiman, metode triple dapat dijadikan cara untuk meramalkan data yang mengandung faktor musiman tersebut Makridakis, dkk (1999). Secara sederhana, metode Triple Exponential Smoothing dapat dibagi menjadi dua tahapan perhitungan yaitu proses inisialisasi dan perhitungan forecasting Turban, E., dkk (2008). Acuan dari skripsi ini yaitu buku Supply Chain Management karya Sunil Chopra dan Peter Meindl. 


\subsubsection{Proses Inisialisasi}

Langkah paling awal adalah memasukkan data permintaan barang minimal dalam satu musim. Dari data yang ada, dilakukan proses deseasonalizing yaitu proses menghilangkan pengaruh musim dari data yang ada sehingga akan ditemukan deseasonalized demand sementara menggunakan rumus:

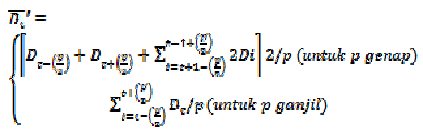

Hasil dari deseasonalizing tersebut tidak menunjukkan demand / permintaan yang sesungguhnya. Data deseasonalized demand tersebut harus diolah kembali menggunakan metode regresi linier sederhana. Analisis regresi linier sederhana adalah hubungan secara linier antara satu variabel independen $(\mathrm{X})$ dengan variabel dependen $(\mathrm{Y})$. Analisis ini untuk mengetahui arah hubungan antara variabel independen dengan variabel dependen apakah positif atau negatif dan untuk memprediksi nilai dari variabel dependen apabila nilai variabel independen mengalami kenaikan atau penurunan.

Dalam hal ini, nilai deseasonalized demand sementara dapat digunakan untuk menentukan nilai level serta proyeksi trend dalam metode peramalan. Bentuk umum rumus regresi linier dinyatakan dalam $Y=a+b t$. Jika dijabarkan lebih lanjut akan ditemukan persamaan regresi linier untuk diseasonal demand dengan sebelumnya menentukan nilai trend dan level menggunakan rumus di bawah ini:

$$
\begin{aligned}
& T_{0}=\frac{n \sum t \overline{D_{t}}-(\Sigma t)\left(\Sigma \overline{D_{t}}\right)}{n \Sigma t^{2}-(\Sigma t)^{2}} \\
& L_{0}={\overline{D_{t}}}^{\prime}-T_{0} \cdot \bar{t} \\
& \overline{D_{t}}=L_{0}+T_{0} \cdot t
\end{aligned}
$$

Setelah masing-masing periode mendapatkan nilai demand (permintaan sesungguhnya) dan deseasonal demand, maka kita bisa menentukan nilai seasonal factor sementara dengan rumus:

$$
\overline{s_{t}}=\frac{D_{t}}{D_{t}}
$$

Setelah masing-masing data mendapatkan nilai seasonal factor sementara, saatnya untuk menentukan rata-rata dari seasonal factor sementara tersebut untuk digunakan dalam perhitungan peramalan yang sesungguhnya.

$$
S_{i}=\frac{\sum_{j=0}^{\gamma-1} s_{j p+1}}{r}
$$

Keterangan:

$\overline{D_{t}} l:$ Deseasonalized demand sementara periode ke $t$

$p \quad$ : Jumlah periode dalam satu musim (dalam hal ini 1 tahun dinyatakan dalam 1 musim sehingga jumlah periode $=12$ )

$T_{0}$ : Nilai proyeksi trend pada periode ke 0

$L_{0}$ : Nilai level pada periode ke 0

$n \quad$ : Jumlah data

$\overline{\bar{D}}_{t}^{\prime}$ : Rata-rata deseasonalized demand sementara

$\overline{S_{t}} \quad$ : Nilai seasonal factor sementara

$S_{i}$ : Nilai seasonal factor pada periode ke $i$ (diambil dari rata-rata seasonal factor)

$r \quad$ : jumlah data yang dikalkulasi

\subsubsection{Perhitungan forecasting}

Pada perumusan forecasting dijumpai nilai $\alpha, \beta$ dan $\gamma$. Nilai konstanta pemulusan dipilih di antara 0 dan 1 karena berlaku $0<\alpha<1$. Apabila pola historis dari data aktual permintaan sangat bergejolak atau tidak stabil dari waktu ke waktu, nilai $\alpha$ yang dipilih adalah yang mendekati 1 . Pola historis dari data aktual permintaan tidak berfluktuasi atau relatif stabil dari waktu ke waktu, $\alpha$ yang dipilih adalah yang nilainya mendekati nol Gaspersz, V., dkk (1998).

Setelah nilai $\alpha, \beta$ dan $\gamma, L_{0}, T_{0}$ serta seasonal factor telah ditemukan maka kemudian masuk ke rumus inti untuk menentukan forecasting.

$$
\begin{aligned}
& L_{t+1}-\alpha\left(D_{t+1} / S_{t+1}\right)+(1-\alpha)\left(L_{t}+T_{t}\right) \\
& T_{t+1}=\beta\left(L_{t+1}-L_{t}\right)+(1-\beta) T_{t} \\
& S_{t+p+1}=\gamma\left(D_{t+1} / L_{t+1}\right)+(1-\gamma) S_{t+1} \\
& F_{t+1}=\left(L_{t}+T_{t}\right) S_{t+1}
\end{aligned}
$$

Keterangan :

$L_{t} \quad$ : Nilai level pada periode ke $t$

$T_{t} \quad$ : Nilai trend pada periode ke $t$

$S_{t}$ : Nilai seasonal factor pada periode ke $t$

$\alpha$ : Nilai konstanta untuk pemulusan keseluruhan atau level

$\beta \quad$ : konstanta pemulusan untuk trend

$\gamma \quad$ : konstanta pemulusan untuk musiman

$p \quad$ : Jumlah periode dalam 1 musim

$F_{\bar{z}}$ : Forecasting pada periode ke $t$

\section{Metodologi Penelitian} waterfall: 


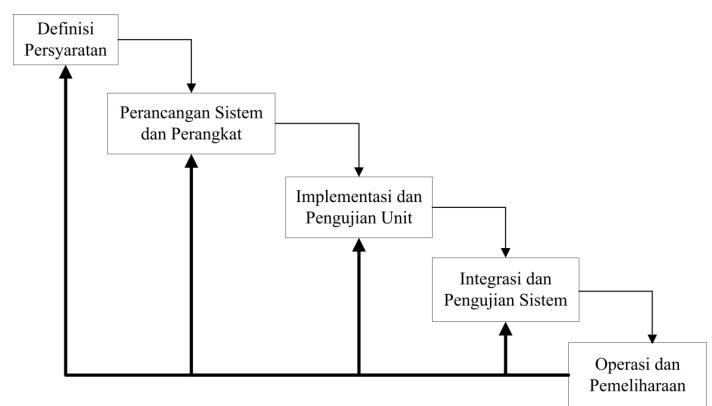

Gambar 1. Metode waterfall

\section{Analisis dan Perancangan}

\subsection{Analisis Sistem}

Pengembangan Sistem Informasi Peramalan Penjualan Guna Menentukan Kebutuhan Bahan Baku Pupuk Menggunakan Metode Triple Exponential Smoothing ini bertujuan untuk membantu proses peramalan stok bahan baku pupuk di PT. Petrokimia Gresik. Proses peramalan pada sistem ini menggunakan metode Triple Exponential Smoothing, dimana data yang diolah mengandung unsur musiman dan trend. Data yang digunakan dalam proses peramalan stok bahan baku pupuk adalah data aktual penjualan pupuk tahun 2013, 2014, dan 2015.

\subsection{Usecase Diagram}

Usecase diagram pada sistem peramalan ini ditujukan untuk admin dan user. Berikut usecase diagram untuk admin.

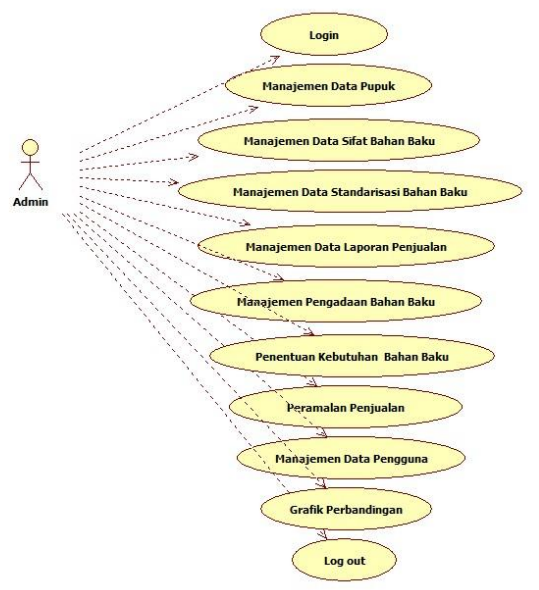

Gambar 2. Usercase admin

\subsection{Flowchart}

Berikut flowchart untuk admin pada sistem peramalan yang dibuat.

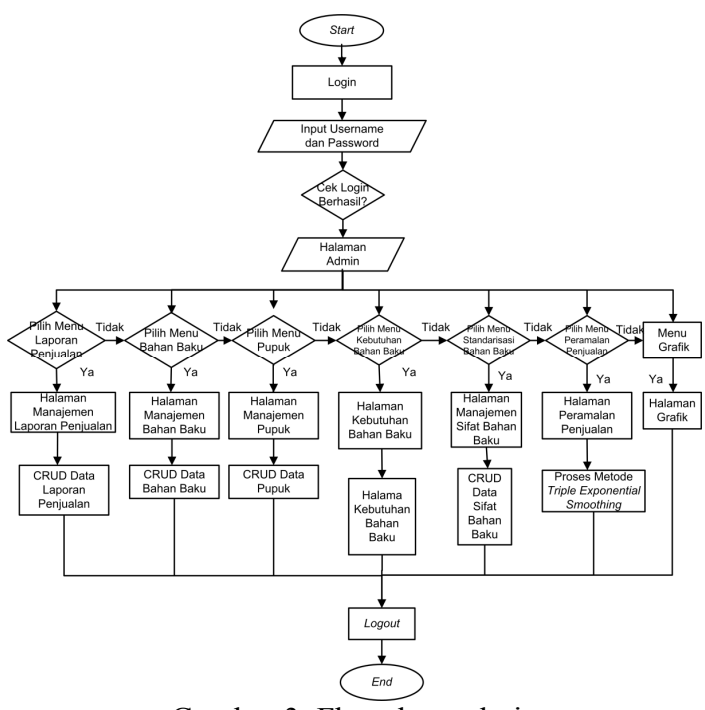

Gambar 3. Flowchart admin

\subsection{ERD (Entity Relationship Diagram)}

ERD pada sistem peramalan yang dibuat ditunjukkan pada Gambar 4.

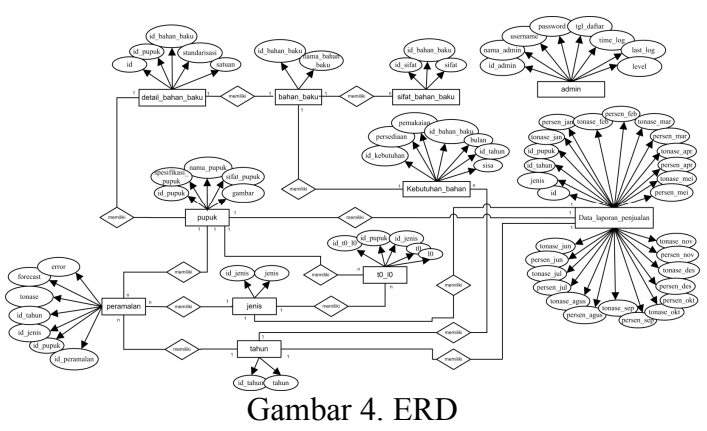

ERD pada sistem peramalan terdiri dari 11 entitas yaitu admin, sifat_bahan_baku, bahan_baku, detail_bahan_baku, data_laporan_penjualan, kebutuhan_bahan, pupuk, t0_10, jenis, tahun, dan peramalan.

\section{Implementasi}

Implemetasi dari interface sistem peramalan adalah sebagaiman gambar berikut.

\subsection{Halaman Peramalan dengan Metode Triple Exponential Smoothing}

Pada halaman metode pengguna dapat melihat hasil peramalan data penjualan baik pupuk subsidi maupun non subsidi seperti ditunjukkan pada Gambar 5. 


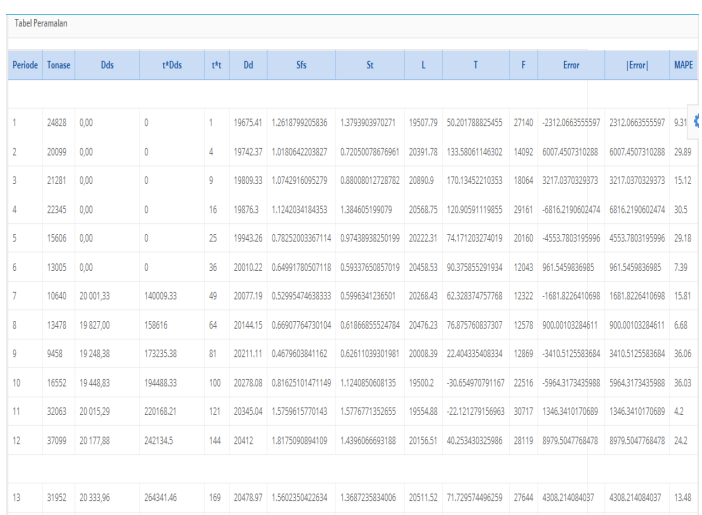

Gambar 5. Halaman permalan penjualan pupuk

\subsection{Halaman Grafik}

Pada halaman grafik pengguna dapat melihat perbandingan antar data aktual penjualan dengan data hasil peramalan penjualan pupuk seperti ditunjukkan Gambar 6 .

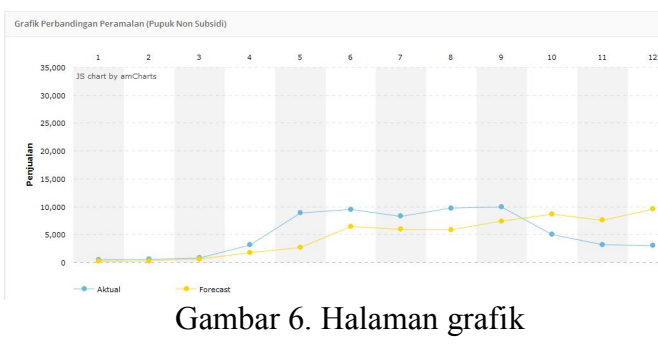

\subsection{Halaman Stok Bahan Baku}

Pada halaman stok bahan baku pengguna dapat melihat informasi mengenai peramalan stok bahan baku seperti ditunjukkan Gambar 7 .

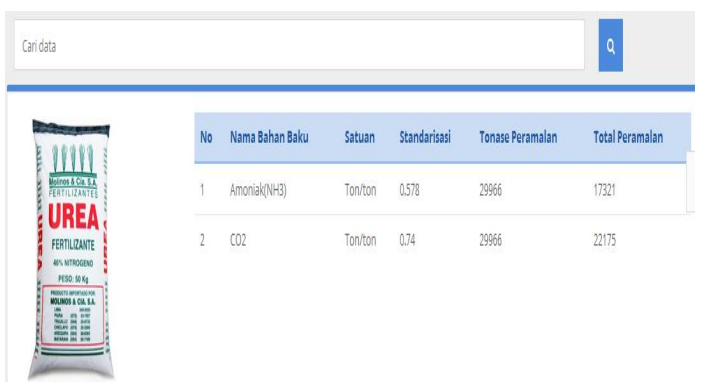

Gambar 7. Halaman stok bahan baku pupuk

\section{Pengujian dan Pembahasan}

\subsection{Perbandingan Excel dengan Sistem}

Hasil pehitungan di excel situnjukkan pada Tabel 1.
Tabel 1. Hasil perhitungan excel

\begin{tabular}{|c|c|c|c|c|}
\hline $\begin{array}{c}\text { Periode } \\
\text { (t) }\end{array}$ & $\begin{array}{l}\text { Bulan- } \\
\text { Tahun }\end{array}$ & Demand (D) & $\mathbf{F}$ & $\begin{array}{c}\text { MAP } \\
\text { E }\end{array}$ \\
\hline \multicolumn{5}{|l|}{$\mathbf{0}$} \\
\hline 1 & Jan-13 & 24,828 & & \\
\hline 2 & Feb-13 & 20,099 & & \\
\hline 3 & Mar-13 & 21,281 & & \\
\hline 4 & Apr-13 & 22,345 & & \\
\hline 5 & Mei-13 & 15,606 & & \\
\hline 6 & Jun-13 & 13,005 & & \\
\hline 7 & Jul-13 & 10,640 & & \\
\hline 8 & Agu-13 & 13,478 & & \\
\hline 9 & Sep-13 & 9,458 & & \\
\hline 10 & Okt-13 & 16,552 & & \\
\hline 11 & Nov-13 & 32,063 & & \\
\hline 12 & Des-13 & 37,099 & & \\
\hline 13 & Jan-14 & 31,952 & 27,644 & $11 \%$ \\
\hline 14 & Feb-14 & 8,791 & 15,376 & $23 \%$ \\
\hline 15 & Mar-14 & 18,702 & 17,597 & $17 \%$ \\
\hline 16 & Apr-14 & 29,735 & 26,831 & $20 \%$ \\
\hline 17 & Mei-14 & 21,811 & 19,117 & $22 \%$ \\
\hline 18 & Jun-14 & 10,702 & 12,170 & $6 \%$ \\
\hline 19 & Jul-14 & 16,689 & 11,926 & $12 \%$ \\
\hline 20 & Agu-14 & 15,594 & 13,104 & $3 \%$ \\
\hline 21 & Sep-14 & 16,052 & 13,185 & $39 \%$ \\
\hline 22 & Okt-14 & 24,206 & 24,393 & $47 \%$ \\
\hline 23 & Nov-14 & 34,780 & 35,502 & $11 \%$ \\
\hline 24 & Des-14 & 25,786 & 33,369 & $10 \%$ \\
\hline 25 & Jan-15 & 28,009 & 30,763 & $4 \%$ \\
\hline 26 & Feb-15 & 15,277 & 15,831 & $80 \%$ \\
\hline 27 & Mar-15 & 14,106 & 19,874 & $6 \%$ \\
\hline 28 & Apr-15 & 34,196 & 29,416 & $1 \%$ \\
\hline 29 & Mei-15 & 23,476 & 21,185 & $3 \%$ \\
\hline 30 & Jun-15 & 13,317 & 13,159 & $23 \%$ \\
\hline 31 & Jul-15 & 10,185 & 13,718 & $18 \%$ \\
\hline 32 & Agu-15 & 9,625 & 13,838 & $11 \%$ \\
\hline 33 & Sep-15 & 14,106 & 13,177 & $18 \%$ \\
\hline 34 & Okt-15 & 30,810 & 23,350 & $4 \%$ \\
\hline 35 & Nov-15 & 33,203 & 34,859 & $0 \%$ \\
\hline \multirow[t]{2}{*}{36} & Des-15 & 28,314 & 31,862 & $24 \%$ \\
\hline & & & 29,966 & \\
\hline
\end{tabular}

Hasil perhitungan di sistem ditunjukkan pada Gambar 8 . 


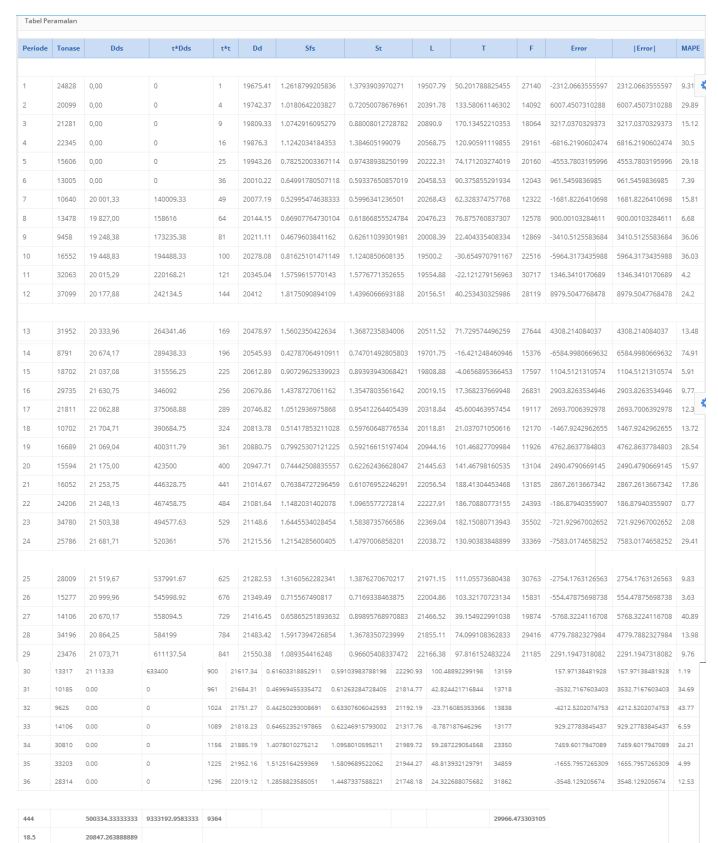

Gambar 8. Hasil hasil peramalan penjualan

\subsection{Menghitung Kesalahan Peramalan}

Pada peramalan dapat dianalisi kesalahan atau error dari nilai peramalan, terhadap data aktual yang didapatkan. Kesalahan peramalan dapat dijelaskan dengan selisih antara permintaan aktual dengan nilai peramalan.Metode analisis kesalahanatau error dapat menggunakan beberapa metode, salah satu metode yang dapat digunakan yaitu MAPE (Mean Absolute Percentage Error). $M A P E$ merupakan rata-rata dari keseluruhan persentase kesalahan (selisih) antara data aktual dengan data hasil peramalan. Ukuran akurasi dicocokkan dengan data time series, dan ditunjukkan dalam persentase.

$$
\begin{aligned}
& E_{t}=\left(D_{t} \quad F_{t}\right) \\
& A_{t}=\left|E_{t}\right| \\
& M A P E_{n}=\frac{\Sigma_{t=\perp}^{n}\left|\frac{E_{t}}{D_{t}}\right| 1 n n}{n}
\end{aligned}
$$

Keterangan:

E : Nilai Error (kesalahan peramalan)

D : Nilai aktual permintaan

F : Nilai peramalan

A : Nilai absolut dari error (kesalahan peramalan)

Pada Tabel 2 ditampilkan contoh perhitungan kesalahan peramalan pupuk urea subsidi yang meliputi nilai absolut dari error, presentase serta nilai $M A P E$.
Tabel 2. Contoh tabel perhitungan error pupuk subsidi

\begin{tabular}{|l|l|l|l|l|l|}
\hline Periode & Bulan & Forecast & Demand & $\begin{array}{l}\text { Absolute } \\
\text { Error }\end{array}$ & $\begin{array}{l}\text { MAP } \\
\text { E }\end{array}$ \\
\hline 37 & $\begin{array}{l}\text { Janu } \\
\text { ari } \\
201 \\
6\end{array}$ & 29966 & 28256 & 1710 & 6,05 \\
& & & & \\
\hline
\end{tabular}

Keterangan:

- Pada tabel di atas, dengan menggunakan persamaan (6.1) ditemukan nilai kesalahan.

Pada bulan Januari 2016 E $=28256-29966=$ 1710

- Dengan menggunakan persamaan (6.2) nilai A diperoleh dengan memutlakkan hasil perhitungan error.

Pada bulan Januari $2016 \mathrm{E}=-1710 \mathrm{~A}=1710$

- Dengan menggunakan persamaan (6.3) nilai MAPE pada periode 37 diperoleh dari menghitung rata-rata presentase absolut error dari periode ke 37. Begitu juga untuk periode selanjutnya berarti menghitung rata-rata presentase absolut error dari periode 37, dan seterusnya. Nilai MAPE dari bulan Januari 2016 adalah:

$$
\begin{aligned}
& M A P E_{n}=\frac{1710}{28256}=6,05 \% \\
& M A P E=\frac{6,05}{1}=6,05 \%
\end{aligned}
$$

Jadi untuk $M A P E$ pupuk urea subsidi pada bulan januari 2016 adalah sebesar 6,05\%. Perhitungan diatas juga dapat di implementasikan pada pupuk jenis subsidi lainnya dan pupuk jenis non subsidi.

\section{Kesimpulan dan Saran}

\subsection{Kesimpulan}

1. Pengembangan Sistem Informasi Peramalan Penjualan Guna Menentukan Kebutuhan Bahan Baku Pupuk Menggunakan Metode Triple Exponential Smoothing dapat memberikan informasi peramalan penjualan guna menentukan kebutuhan bahan baku pupuk

2. Sistem berhasil melakukan perhitungan peramalan dengan menggunakan metode Triple Exponential Smoothing pada data penjualan pupuk subsidi (sampel hasil peramalan pupuk urea subsidi sebesar 29.966 ton dan menghasilkan peramalan kebutuhan bahan baku amoniak sebesar 17.321 ton dan $\mathrm{CO}_{2}$ sebesar 22.175 ton).

3. Pengujian nilai error (akurasi peramalan) pada bulan januari 2016 menunjukan hasil yang bagus untuk pupuk subsidi (diantara 10\% dan 20\%) 
yaitu 14,63\% dan hasil yang kurang bagus untuk pupuk non subsidi yaitu $34,42 \%$.

4. Aplikasi dapat digunakan sebagai sistem peramalan penjualan guna menentukan kebutuhan bahan baku pupuk subsidi.

5. Aplikasi tidak dapat digunakan sebagai sistem peramalan penjualan guna menentukan kebutuhan bahan baku non subsidi

6. Sistem berhasil melakukan perhitungan

\subsection{Saran}

Berdasarkan hasil peramalan penjualan Exponential Smoothing mendapat rata-rata hasil akurasi yang bagus untuk pupuk subsidi dan hasil yang kurang bagus untuk pupuk non subsidi. Dengan begitu untuk penelitian lebih lanjut disarankan untuk meramalkan penjualan pupuk non subsidi dengan menggunakan metode peramalan yang lain dan menggunakan data time series harian atau tahunan agar bisa dilihat struktur pola datanya yang lebih teratur dibandingkan dengan time series bulanan sehingga diharapkan mendapat hasil peramalan yang lebih bagus.

\section{Daftar Pustaka:}

Makridakis., et all, Metode dan Aplikasi Peramalan. Jakarta: Erlangga, 1999.

Turban, E., Sharda, R, Delen, D., \& David, K., Business Intelligence: A Managerial Approach. Upper Saddle River, NJ: Prentice Hall, 2008.

Power, D., A Brief History of Decision Support System, 2007.

Gaspersz, Vincent., Statistical Process Control :Penerapan Teknik-Teknik Statistikal Dalam Manajemen Bisnis Total. Jakarta : Gramedia Pustaka Utama, 1998.

Chopra, S. and Meindl, P., Supply Chain Management: Strategy, Planning and Operasion, 2nd or 3rd Edition. New Jersey: Pearson Prentice Hall, 2007.

Griffiths, Adam., CodeIgniter 1.7 Professional Development. United of Kingdom: Packt Publishing, 2010.

Anhar., 2010. PHP \& MySql Secara Otodidak. Jakarta: Transmedia.

Wicaksono, Yogi., Membangun Bisnis Online dengan Mambo $++C D$. Jakarta: Elex Media Komputindo, 2008.

Zainun, N. Y., dan Majid, M. Z. A., 2003. Low Cost House Demand Predictor. Universitas Teknologi Malaysia 
Volume 4, Edisi 1, November 2017

$\mathbf{4 2} \mid \mathrm{H}$ a 1 a $\mathrm{m}$ a $\mathrm{n}$ 